\title{
FIRE INFLUENCE ON DYNAMICS OF ABOVE-GROUND PHYTOMASS IN STEPPE PLANT COMMUNITIES IN THE BURTINSKAYA STEPPE (ORENBURG STATE NATURE RESERVE, RUSSIA)
}

\author{
Gulnara Kh. Dusaeva*, Olga G. Kalmykova, Neilya V. Dusaeva \\ Institute of Steppe, Ural Branch of RAS, Russia \\ *e-mail:16guluy@mail.ru
}

Received: 30.09.2018. Revised: 10.07.2019. Accepted: 29.07.2019.

\begin{abstract}
People have significantly influenced on Orenburg region steppes by ploughing large parts of it, or by utilising other parts as mowed grasslands, pastures or abandoning crop production on the old abandoned fields. Frequent fires are another serious threat to the biodiversity of the steppes in the region. The main cause of fires is the anthropogenic factor. This problem is relevant not only for managed areas, but also for Protected Areas. The need to study the fire effects on ecosystems in the Orenburg State Nature Reserve (Russia) has appeared for a long time, once it cleared that a special regime of Protected Areas could not always preserve steppes of fire influence due to the steppe's specifics (i.e., significant length of the fire front and a burnt area, high speed of a fire spread under strong wind). At the same time, it is most relevant to conduct environmental studies in the Protected Areas as ecosystems, least managed and disturbed by humans. It is supplemented by excluding of any impacts within these areas and using data of long-term research accumulated over previous years. In 2015-2016, we carried out the post-fire dynamics of the stock of the above-ground phytomass in the site «Burtinskaya Steppe» in the Orenburg State Natural Reserve. The study area is located in the steppe zone of the Pre-Ural region. In August 2014, more than $20 \mathrm{~km}^{2}$ of the steppe area was on fire. We established six study sites in this area. Each of them included a control (unburnt) and a burnt plots. In each plant community, we conducted the geobotanical surveys and mowing of the above-ground phytomass in spring (May), summer (June), late summer (August), autumn (September). The obtained samples were dried, divided into groups (grasses, forbs, dwarf semi-shrubs) and then weighted. We compared both unburnt and burnt study plots, and found statistically significant differences between them using the Mann-Whitney U-test $(\alpha<0.05)$ in the total stock of the above-ground phytomass, stock of the dead phytomass, the standing dead phytomass, and litter. In the burnt plant communities, the accumulation peaks of the living grass and forbs phytomass shifted compared to the unburnt plots. During the first two post-fire years, only stock of the living phytomass and its components (grasses, forbs, dwarf semi-shrubs) were restoring. Other components of the above-ground phytomass did not reach the control values. Our data were part of a project for creation a framework to monitor ecosystems in the preserved area after the 2014 fire impact.
\end{abstract}

Key words: above-ground phytomass, Orenburg region, Protected Area, pyrogenic factor

\section{Introduction}

In recent years, the fire impact on steppe landscapes has reached a catastrophic scale. The activation of fire phenomena has been recorded in the steppes of the Volga-Ural region. Analysis of the available Landsat space images dated by 1984-2014 in various areas in the Volga-Ural region indicated a sharp increase in number and area of fires starting since the late 1990s (Pavleichik, 2016). Similar conclusions were formulated for other regions of Russia (Dubinin et al., 2011; Tkachuk, 2015).

Due to the widespread relevance of the fire impact phenomenon, this factor acquires a significant role in the Protected Areas. Even within a state nature reserve, wildfire is a difficult to control component of anthropogenic origin. The fire usually arises as a result of economic activity and rapidly moves to
Protected Areas from adjacent territories (Kalmykova, 2006). Therefore, the site «Burtinskaya Steppe» could be completely burnt out over 5-6 years due to the frequent fires (Pavleichik, 2015).

The fire impact on the steppe vegetation has been studied comprehensively. However, it is still assessed ambiguously. Research of the fire influence on the vegetation cover of the steppes has been carried out in Europe (Deák et al., 2012, 2014; Valkó et al., 2014, 2016, 2017; Pereira et al., 2015, 2016, 2017; Ruprecht et al., 2016), USA (Engle et al., 1989; Fuhlendorf \& Engle, 2004; Davies et al., 2007, 2012; Augustine \& Milchunas, 2009; Augustine et al., 2010; Bates et al., 2009; Scheintaub et al., 2009; Twidwell et al., 2012; Winter et al., 2013, 2015; Dufek et al., 2018; Dickson et al., 2018), Australia (Allan et al., 2003; Andersen et 
al., 2008). Most of these studies were conducting on pastures. On these sites, fire influence has seriously both environmental and economic consequences (Rostagno et al., 2006; Davies et al., 2008, 2017; Bates et al., 2009; Winter et al., 2015; Mata-González et al., 2018). In Russia, the impact of fires on the steppe vegetation has been studied in the Orenburg region (Rozhanets-Kucherovskaya, 1926; Ryabtsov, 2002, 2006; Ryabtsov \& Safonov, 2002; Ryabinina, 2003; Kalmykova, 2006; Ryabinina et al., 2010), Volgograd region (Ryabinina, 2013, 2014), Samara region (Ilyina, 2011), Republic of Bashkortostan (Yunusbayev et al., 2007; Yunusbayev \& Abdulina, 2010), Republic of Tyva (Titlyanova \& Sambuu, 2016), Dauria region (Tkachuk, 2015; Tkachuk \& Denisova, 2015).

Protected Areas are the most suitable sites to conduct long-term studies of the fire impact on natural ecosystems. In Russia, the fire impact on the vegetation cover of steppe Protected Areas has been studied previously (Lavrenko, 1950; Fedyunkin, 1953; Ryabtsov, 2002, 2006; Ryabinina, 2003; Kalmykova, 2006; Kandalova, 2007; Skolzneva \& Skolznev, 2003; Ryabinina, 2013, 2014; Kudryavtsev, 2016). Extensive, thorough and detailed study of the fire influence on the steppe vegetation of state nature reserves has been carried out in Ukraine (Shalyt \& Kalmykova, 1935; Drohobych, 2000; Lysenko, 2006; Timoshenkov \& Timoshenkova, 2007; Gavrilenko, 2008; Hoffman, 2015). Such studies have been conducted in Europe (Deák et al., 2012; Pereira et al., 2016; Kertŭsz et al., 2017), North America (Fuhlendorf \& Engle, 2001; Davies et al., 2012), Australia (Allan et al., 2003; Andersen et al., 2008).

The stock of the above-ground phytomass and its dynamics are considered as objective indicators. These allow assessing the fire impact on vegetation cover. In Russia, the most detailed consequences of the fire influence on the aboveground phytomass of the steppe vegetation of Tyva region has been established by Sambuu \& Dapyldai (2016), Titlyanova \& Sambuu (2016). Similar studies have been carried out in the grasslands of Turkey (Gullap et al., 2018), steppes of Hungary (Valky et al., 2016, 2017). Such studies are widely represented in North America, where the frequency, severity and intensity of fires on the above-ground phytomass of prairies with focus on their pasturable use have been estimated (Engle et al., 1989; Davies et al., 2007; Augustine \& Milchunas, 2009; Bates et al., 2009; Augustine et al., 2010; Dufek et al., 2018). In North Amer- ica, the fire frequency and intensity through the phytomass stock regulation have been considered (Davies et al., 2017); these have also been studied in relation to the Russian steppe ecosystems (Tishkov, 2003).

The research of steppe ecosystems before and after the fire influence is necessary to develop methods and approaches for steppe preservation from the fire influence effects and preventing their burnout. The study of the vegetation cover in steppes plays a special role in formation of such ideas. The fire affects all components of the steppe plant communities. It causes remarkable transformations of communities, changing their structure, the processes of formation of the living and dead phytomass, modifying the community composition.

The aim of the study was to analyse the postfire dynamics of the stock of the above-ground phytomass in the steppe plant communities. We established the following tasks: 1) to identify the specificity of the fire effect on the stock of the living phytomass and its components; 2) to study the post-fire dynamics of the dead phytomass and its components.

\section{Material and Methods}

Investigations were conducted on the site «Burtinskaya Steppe» in the Orenburg State Nature Reserve (Belyaevsky district, Orenburg region, Russia). This site has an area of $45 \mathrm{~km}^{2}$ and is located within the eastern part of the Pre-Ural regional deflection (Chibilev, 1996). It is located in the subzone of forbs-bunchgrass of the TransVolga-Kazakhstan steppes (Ogureyeva, 1999; Safronova \& Kalmykova, 2012).

On the basis of the Selyaninov Hydrothermal Coefficient values, the weather conditions of the study period were very arid in 2014 , slightly arid in 2015, and satisfactory wet in 2016 (Table 1).

The 2014-2015 winter was characterised by a low amount of snow. The maximum snow cover $(34 \mathrm{~cm})$ was noted early February. The lack of herb cover on the burnt sites during the snow cover formation determined its fragmentary distribution, mainly in the lowlands within the study area (Pavleichik et al., 2016) (Fig. 1).

The 2015-2016 winter was characterised by a high precipitation amount and high temperature in combination with a series of thaws. Similar weather conditions and partial vegetation restoration in 2015 caused an even larger snow cover (Pavleichik et al., 2016). 
Table 1. Climatic data in the study area in 2014-2016

\begin{tabular}{|c|c|c|c|}
\hline \multirow{2}{*}{ Month } & \multicolumn{3}{|c|}{ Study years } \\
\cline { 2 - 4 } & 2014 & 2015 & 2016 \\
\hline Average monthly air temperature, ${ }^{\circ} \mathrm{C}$ \\
\hline May & 18.8 & 15.7 & 16.2 \\
\hline June & 20.9 & 23.4 & 18.8 \\
\hline July & 19.9 & 21.5 & 21.6 \\
\hline August & 24.5 & 19.5 & 26.0 \\
\hline September & 14.9 & 17.2 & 14.6 \\
\hline Total monthly precipitation, $\mathrm{mm}$ \\
\hline May & 41.5 & 90.3 & 77.2 \\
\hline June & 31.6 & 56.8 & 81.9 \\
\hline July & 26.4 & 28.9 & 71.3 \\
\hline August & 16.6 & 25.3 & 8.3 \\
\hline September & 12.9 & 14.5 & 62.2 \\
\hline $\begin{array}{l}\text { Selyaninov Hydrothermal Coefficient } \\
\text { meaning during vegetation period }\end{array}$ & 0.4 & 0.7 & 1.0 \\
\hline \multicolumn{3}{|c|}{} \\
\hline
\end{tabular}

Since the establishment of the site «Burtinskaya Steppe» five large fire evidences have been registered. In 1991, an area of $14.7 \mathrm{~km}^{2}$ was burnt, in $1995-38.9 \mathrm{~km}^{2}$, in $1998-42.5 \mathrm{~km}^{2}$, in $2003-$ $40.5 \mathrm{~km}^{2}$, in $2009-18.5 \mathrm{~km}^{2}$. Before the 2014 fire, the study area did not burn during 6-11 years. Before 2014, study sites №1, 3, 6 burnt the last time in 2003, and study sites №2, 4, 5 burnt the last time in 2009. Most of the fires started from the adjacent agricultural areas. The fires occurred the most frequent in late summer and autumn.

The study of vegetation cover was carried out during the vegetation periods in 2015-2016. Six study sites were established in the site «Burtinskaya Steppe» and its buffer zone. The study sites №1, 3 , 4 were located on the plain areas with a small slope. The study site №5 was situated on a hill top. The study sites №2, 6 were located on the slopes of different exposures. The plant communities in the study sites belonged to Stipetea zalesskii (№1, 2, 3, 5, 6) and Stipetea lessingiana (№4) formations. These plant communities are most common on the site «Burtinskaya Steppe» (Kalmykova, 2009, 2012). The study sites №1, 3 had been stronger overgrazed before establishment of the Protected Area. The study site №4 located in the buffer zone of the site «Burtinskaya Steppe» is an old abandoned field. The study sites №2, 5, 6 were located in the undisturbed steppe.

Each study site consisted of a burnt (A) and unburnt (B) plot. We planned the location of study plots on the basis of their availability, diversity (e.g. landscape position, vegetation cover) and the possibility to compare (burnt vs. unburnt). We established the study sites at the periphery of an area burnt in 2014 (Fig. 2), where the unburnt plots were located as close as possible to the burnt ones.

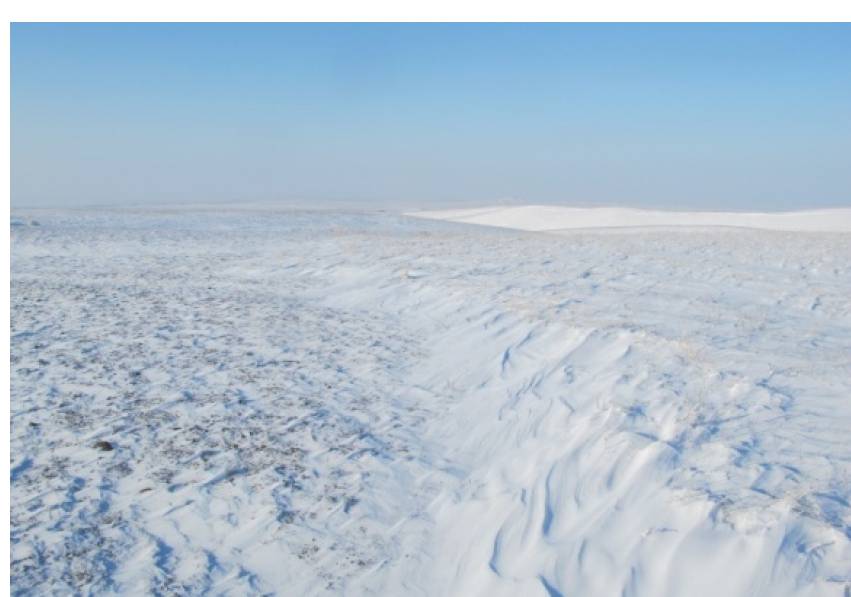

Fig. 1. Snow distribution at the boundary of burnt (left) and unburnt (right) areas on the site «Burtinskaya Steppe» (Orenburg State Nature Reserve, Russia), December 2014.

We performed geobotanical surveys using widely accepted geobotanical methodics (Walter \& Alekhin, 1936; Yaroshenko, 1961; Lavrenko \& Korchagin, 1964, 1972; Rabotnov, 1992) on permanent $10 \times 10 \mathrm{~m}$ sample plots. The geobotanical surveys of each plant community included the total projective cover of the phytocenosis and its species composition. For each species, we counted its abundance, projective cover and the character of spatial location. The study of the above-ground plant substance dynamics has been performed according to Bazilevich et al. (1978). In each plant community, the mowing has been carried out in spring (May), summer (June), late summer (August) and autumn (September). The sample plants were cut at the level of the soil on study plots of $0.25 \mathrm{~m}^{2}$ at three replicates (three copies per plot). Under laboratory conditions, we weighted the samples and estimated the stock of each component of plant matter (mass of plant organs per unit area at the time of the study). The following abbreviations are used: $G$ - stock of the above-ground living phytomass, L - litter, D stock of the above-ground standing dead phytomass. Components of the stock of the above-ground living phytomass are abbreviated as $\mathrm{G}_{\text {gr. }}$ - grasses, $\mathrm{G}_{\text {for. }}$ forbs, $\mathrm{G}_{\mathrm{dsh} .}-$ dwarf semi-shrubs, D + L - stock of the above-ground dead phytomass. Components of the standing dead phytomass are abbreviated as $\mathrm{D}_{\text {gr }}$ - grasses, $D_{\text {for. }}-$ forbs, $D_{\text {dsh }}$ - dwarf semi-shrubs. All above-ground phytomass was dried to air-dry state. Then it was weighted with an accuracy of $0.05 \mathrm{~g}$.

The statistical data processing was performed using Statistica 6.1 software. To assess the statistical significance of the differences in the stock of the phytomass and its components between the burnt and unburnt plots, we used the Mann-Whitney U-test $(\alpha<0.05)$. 


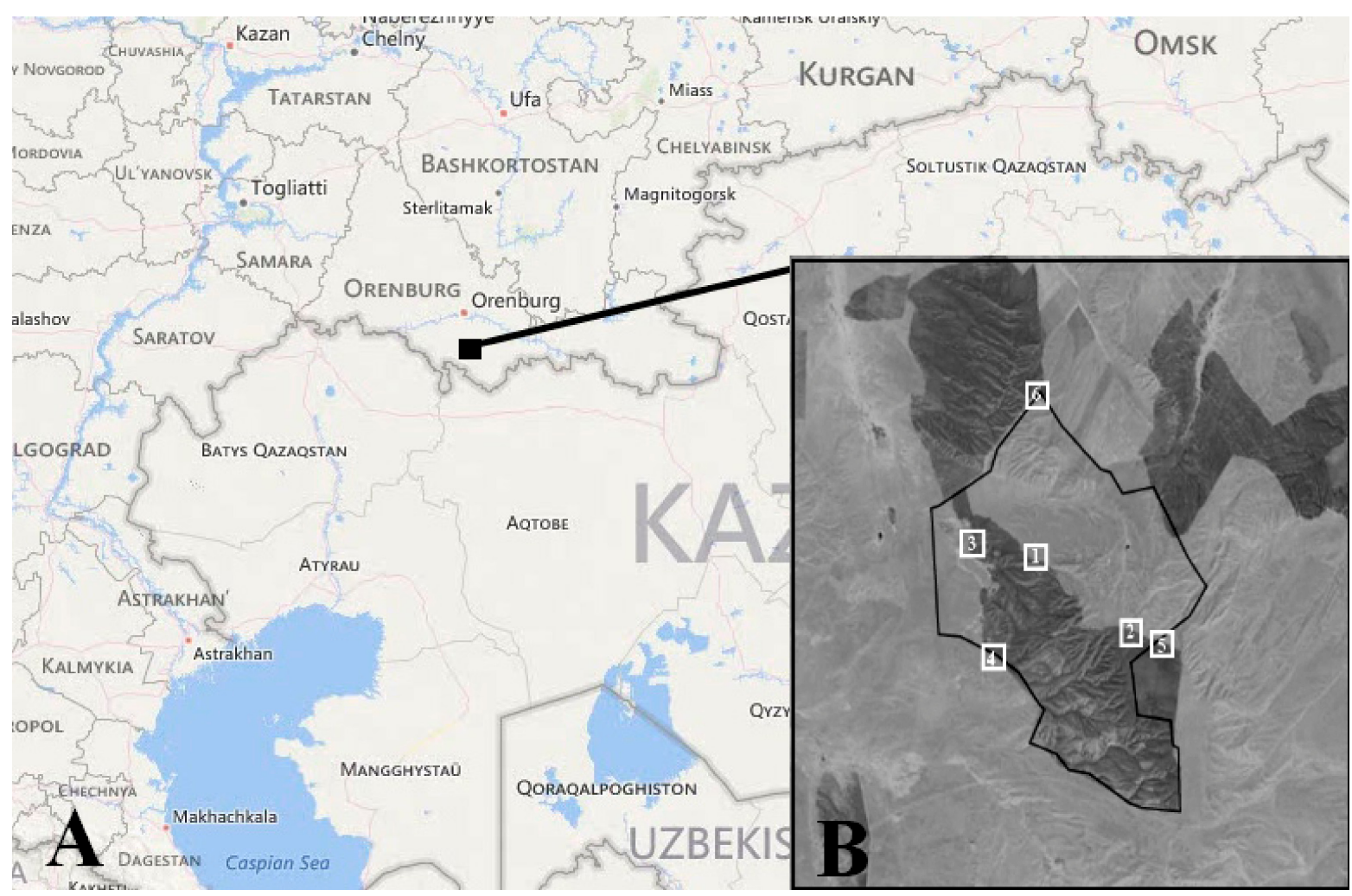

Fig. 2. The location of the study area. A - location of the site «Burtinskaya steppe» in the Orenburg State Nature Reserve. B - area burnt in 2014 (dark-grey colour) and map of study site locations. The black line is the boundary of the site «Burtinskaya Steppe».

\section{Results}

\section{Total stock of the above-ground phytomass}

During the study period, the total stock of the above-ground phytomass $(\mathrm{G}+\mathrm{D}+\mathrm{L})$ on all burnt plots was always lower than on the unburnt ones. At the same time, the total stock of the above-ground phytomass on unburnt plots exceeded those on the burnt ones at 2-11 times in 2015, and at 1-3 times in 2016. The Mann-Whitney U-test confirmed statistically significant differences at a significance level of $\alpha<0.05$ in all study sites (Table 2). Despite an increase in the total stock of the above-ground phytomass on the burnt plots in 2016, the difference between them and unburnt plots still remained quite large.

On the unburnt plots, the maximum stock of the above-ground phytomass was mainly associated with the beginning or end of the vegetation period over both study years. This is explained by an increase in the dead phytomass during this period (Fig. 3). On the contrary, the largest stock of the above-ground phytomass on the burnt plots was always associated with the largest stock of the living above-ground phytomass. Therefore, maximum values occurred most often in the first half of the season - in June (Fig. 4).

The dynamics of the above-ground phytomass stock on all six burnt study plots was similar with a peak in June and a decline during the following months. The composition and structure of plant communities is simplified. The ratio of the above-ground phytomass components and the role of certain species in its formation changed (Fig. 3, Fig. 4). On the contrary, plant communities on the unburnt plots are characterised by a higher ecological and biomorphological fullness with preservation of the phytocoenotic role of species, manifested in a certain period of the vegetation period.

Over the whole study period, on the unburnt plots, the stock of the above-ground dead phytomass exceeded the stock of the above-ground living phytomass by 1.2-9.0 times. On the burnt study plots, the opposite situation was demonstrated at the beginning and middle of the 2015 vegetation period. The stock of the living phytomass was 1.2-7 times higher than the stock of the dead phytomass. In some cases (in May in study site №3, 6), this difference counted hundreds of times.

\section{Stock of the living phytomass}

The stock of the living phytomass $(\mathrm{G})$ on both the burnt and unburnt plots accumulated similarly. Their values predominantly increased May to June due to the active development of the dominated forbs-bunchgrass vegetation (Fig. 5, Fig. 6). By a late vegetation period, their values gradually decreased, once the most of the living phytomass changed to the standing dead phytomass or litter, by reaching minimum values. 


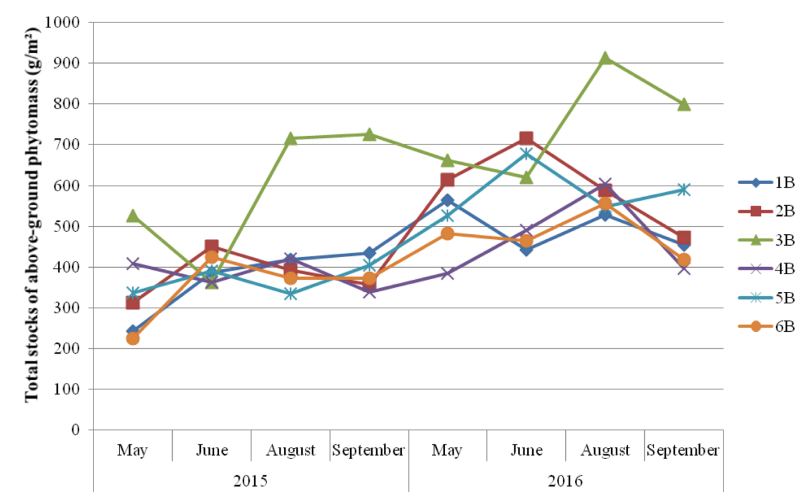

Fig. 3. Dynamics of the total stock of above-ground phytomass on unburnt plots.

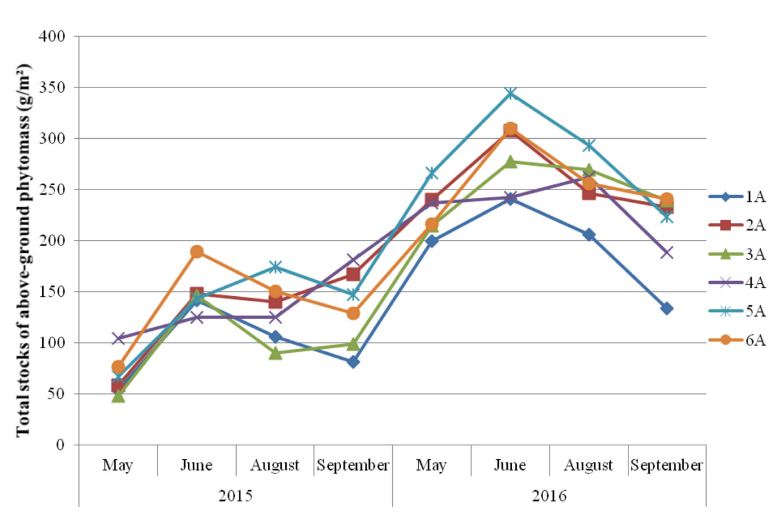

Fig. 4. Dynamics of the total stock of above-ground phytomass on burnt plots.

Table 2. The stock of the above-ground phytomass (mean $\pm \mathrm{SE}$ ) on burnt $(\mathrm{A})$ and unburnt $(\mathrm{B}) \mathrm{plots}\left(\mathrm{g} / \mathrm{m}^{2}\right)$

\begin{tabular}{|c|c|c|c|c|c|c|c|c|c|c|c|}
\hline \multirow{2}{*}{ Plots } & \multicolumn{11}{|c|}{ Parametres } \\
\hline & $G+D+L$ & G & $\mathrm{G}_{\mathrm{gr.}}$ & $G_{\text {for. }}$ & $\mathrm{G}_{\mathrm{dsh} .}$ & $\mathrm{D}+\mathrm{L}$ & $\mathrm{D}$ & $\mathrm{D}_{\mathrm{gr} .}$ & $D_{\text {for. }}$ & $\mathrm{D}_{\mathrm{dsh}}$. & $\mathrm{L}$ \\
\hline \multicolumn{12}{|c|}{2015 year } \\
\hline $1 \mathrm{~A}$ & $96 \pm 13^{*}$ & $70 \pm 11 *$ & $30 \pm 6$ & $12 \pm 3$ & $11 \pm 3$ & $31 \pm 6^{*}$ & $20 \pm 5^{*}$ & $8 \pm 2 *$ & $14 \pm 3$ & $0.5 \pm 0.3 *$ & $11 \pm 3 *$ \\
\hline $1 \mathrm{~B}$ & $371 \pm 30^{*}$ & $109 \pm 15^{*}$ & $54 \pm 11$ & $23 \pm 9$ & $29 \pm 9$ & $262 \pm 25^{*}$ & $84 \pm 10^{*}$ & $64 \pm 10^{*}$ & $12 \pm 4$ & $5 \pm 3 *$ & $178 \pm 21^{*}$ \\
\hline $2 \mathrm{~A}$ & $143 \pm 14 *$ & $89 \pm 11$ & $61 \pm 7$ & $13 \pm 3$ & $13 \pm 6$ & $53 \pm 9^{*}$ & $50 \pm 8^{*}$ & $16 \pm 3^{*}$ & $33 \pm 7$ & $8 \pm 3$ & $3 \pm 1.8^{*}$ \\
\hline $2 \mathrm{~B}$ & $378 \pm 22 *$ & $110 \pm 15$ & $69 \pm 8$ & $23 \pm 9$ & $15 \pm 4$ & $268 \pm 16^{*}$ & $184 \pm 16^{*}$ & $130 \pm 7^{*}$ & $21 \pm 5$ & $21 \pm 13$ & $84 \pm 7 *$ \\
\hline $3 \mathrm{~A}$ & $96 \pm 12 *$ & $54 \pm 11^{*}$ & $29 \pm 4^{*}$ & $25 \pm 10$ & $0.2 \pm 0.1$ & $42 \pm 9^{*}$ & $34 \pm 8^{*}$ & $16 \pm 7^{*}$ & $22 \pm 6$ & $1 \pm 3$ & $8 \pm 4^{*}$ \\
\hline $3 \mathrm{~B}$ & $583 \pm 64^{*}$ & $86 \pm 9^{*}$ & $62 \pm 8^{*}$ & $23 \pm 6$ & $1.5 \pm 1.3$ & $496 \pm 61^{*}$ & $163 \pm 26^{*}$ & $141 \pm 25^{*}$ & $17 \pm 4$ & $0.06 \pm 0.06$ & $333 \pm 51^{*}$ \\
\hline $4 \mathrm{~A}$ & $130 \pm 12 *$ & $87 \pm 8^{*}$ & $65 \pm 7^{*}$ & $17 \pm 4$ & $5 \pm 2$ & $43 \pm 7^{*}$ & $30 \pm 6^{*}$ & $18 \pm 4^{*}$ & $11 \pm 2$ & $0.7 \pm 2$ & $13 \pm 6^{*}$ \\
\hline $4 \mathrm{~B}$ & $387 \pm 20^{*}$ & $135 \pm 9^{*}$ & $111 \pm 8^{*}$ & $13 \pm 3$ & $11 \pm 3$ & $252 \pm 18^{*}$ & $155 \pm 18^{*}$ & $141 \pm 17^{*}$ & $11 \pm 4$ & $3 \pm 1$ & $97 \pm 7^{*}$ \\
\hline $5 \mathrm{~A}$ & $133 \pm 14^{*}$ & $95 \pm 12$ & $68 \pm 8$ & $21 \pm 7$ & $3 \pm 1$ & $39 \pm 9^{*}$ & $33 \pm 8^{*}$ & $18 \pm 5^{*}$ & $37 \pm 7^{*}$ & $3 \pm 1.5$ & $5 \pm 2 *$ \\
\hline $5 \mathrm{~B}$ & $367 \pm 23^{*}$ & $107 \pm 12$ & $61 \pm 6$ & $36 \pm 8$ & $7 \pm 2$ & $260 \pm 22 *$ & $152 \pm 18^{*}$ & $104 \pm 12 *$ & $12 \pm 4 *$ & $8 \pm 5$ & $108 \pm 13^{*}$ \\
\hline $6 \mathrm{~A}$ & $136 \pm 14^{*}$ & $89 \pm 11$ & $73 \pm 11$ & $8 \pm 2$ & $8 \pm 3$ & $47 \pm 10^{*}$ & $45 \pm 11^{*}$ & $37 \pm 9 *$ & $15 \pm 3^{*}$ & $0.3 \pm 0.3^{*}$ & $2 \pm 1^{*}$ \\
\hline $6 \mathrm{~B}$ & $359 \pm 26^{*}$ & $127 \pm 19$ & $99 \pm 14$ & $9 \pm 3$ & $18 \pm 6$ & $233 \pm 17^{*}$ & $121 \pm 8^{*}$ & $103 \pm 7^{*}$ & $7 \pm 2 *$ & $3 \pm 1 *$ & $111 \pm 12 *$ \\
\hline \multicolumn{12}{|c|}{2016 year } \\
\hline $1 \mathrm{~A}$ & $182 \pm 18^{*}$ & $96 \pm 15$ & $40 \pm 6^{*}$ & $37 \pm 11$ & $17 \pm 6$ & $50 \pm 9^{*}$ & $48 \pm 6^{*}$ & $24 \pm 3^{*}$ & $18 \pm 3$ & $6 \pm 3$ & $50 \pm 9 *$ \\
\hline $1 \mathrm{~B}$ & $497 \pm 21^{*}$ & $120 \pm 8$ & $69 \pm 8^{*}$ & $23 \pm 5$ & $24 \pm 5$ & $247 \pm 17^{*}$ & $131 \pm 12 *$ & $103 \pm 14^{*}$ & $15 \pm 3$ & $11 \pm 3$ & $247 \pm 17^{*}$ \\
\hline $2 \mathrm{~A}$ & $256 \pm 14^{*}$ & $132 \pm 13$ & $80 \pm 11$ & $30 \pm 7$ & $18 \pm 5$ & $39 \pm 8^{*}$ & $85 \pm 5^{*}$ & $65 \pm 6^{*}$ & $12 \pm 2^{*}$ & $7 \pm 3 *$ & $39 \pm 8^{*}$ \\
\hline $2 \mathrm{~B}$ & $597 \pm 35^{*}$ & $177 \pm 21$ & $103 \pm 9$ & $37 \pm 10$ & $34 \pm 10$ & $189 \pm 11^{*}$ & $232 \pm 20^{*}$ & $178 \pm 17^{*}$ & $29 \pm 9^{*}$ & $22 \pm 3^{*}$ & $189 \pm 11^{*}$ \\
\hline $3 \mathrm{~A}$ & $250 \pm 12 *$ & $130 \pm 11$ & $89 \pm 6$ & $37 \pm 8$ & $3.4 \pm 3$ & $34 \pm 7 *$ & $86 \pm 7 *$ & $61 \pm 7^{*}$ & $25 \pm 4$ & $0.7 \pm 0.7$ & $34 \pm 7^{*}$ \\
\hline $3 \mathrm{~B}$ & $748 \pm 54^{*}$ & $126 \pm 15$ & $83 \pm 7$ & $39 \pm 12$ & $5 \pm 3$ & $408 \pm 49 *$ & $214 \pm 23^{*}$ & $191 \pm 23^{*}$ & $22 \pm 4$ & $0.7 \pm 0.4$ & $408 \pm 49^{*}$ \\
\hline $4 \mathrm{~A}$ & $233 \pm 11 *$ & $106 \pm 7$ & $81 \pm 6^{*}$ & $16 \pm 3$ & $9 \pm 3$ & $50 \pm 5^{*}$ & $76 \pm 6^{*}$ & $67 \pm 6^{*}$ & $7 \pm 1$ & $2 \pm 0.8$ & $50 \pm 5^{*}$ \\
\hline $4 \mathrm{~B}$ & $469 \pm 30^{*}$ & $130 \pm 11$ & $103 \pm 6^{*}$ & $19 \pm 5$ & $8 \pm 3$ & $173 \pm 19 *$ & $166 \pm 10^{*}$ & $153 \pm 9 *$ & $9 \pm 2$ & $4 \pm 2$ & $173 \pm 19^{*}$ \\
\hline $5 \mathrm{~A}$ & $282 \pm 17^{*}$ & $145 \pm 19$ & $101 \pm 14$ & $28 \pm 9$ & $14 \pm 4$ & $51 \pm 8^{*}$ & $85 \pm 7 *$ & $70 \pm 7^{*}$ & $11 \pm 3^{*}$ & $5 \pm 2$ & $51 \pm 8^{*}$ \\
\hline $5 \mathrm{~B}$ & $585 \pm 23^{*}$ & $161 \pm 23$ & $81 \pm 8$ & $56 \pm 14$ & $22 \pm 7$ & $262 \pm 13 *$ & $163 \pm 12 *$ & $109 \pm 6^{*}$ & $44 \pm 9 *$ & $8 \pm 2$ & $262 \pm 13^{*}$ \\
\hline $6 \mathrm{~A}$ & $256 \pm 18^{*}$ & $130 \pm 15$ & $89 \pm 11$ & $18 \pm 9$ & $23 \pm 8$ & $34 \pm 4^{*}$ & $91 \pm 6^{*}$ & $77 \pm 5^{*}$ & $7 \pm 2$ & $7 \pm 3$ & $34 \pm 4^{*}$ \\
\hline $6 \mathrm{~B}$ & $480 \pm 30^{*}$ & $109 \pm 9$ & $94 \pm 7$ & $6 \pm 2$ & $9 \pm 2$ & $161 \pm 18^{*}$ & $210 \pm 22 *$ & $197 \pm 23^{*}$ & $10 \pm 4$ & $3 \pm 1$ & $161 \pm 18^{*}$ \\
\hline
\end{tabular}

Note: $*$ - significant differences between burnt and unburnt plots. Significance level: $\alpha<0.05$.

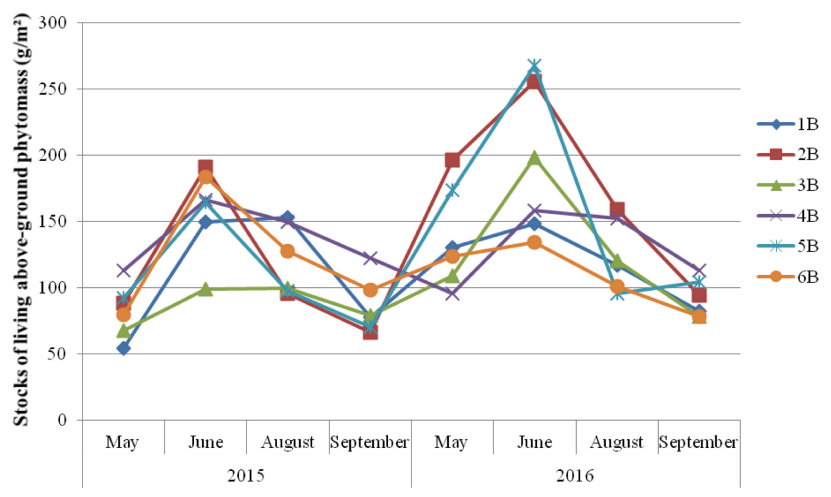

Fig. 5. Dynamics of the stock of the living phytomass on unburnt plots.

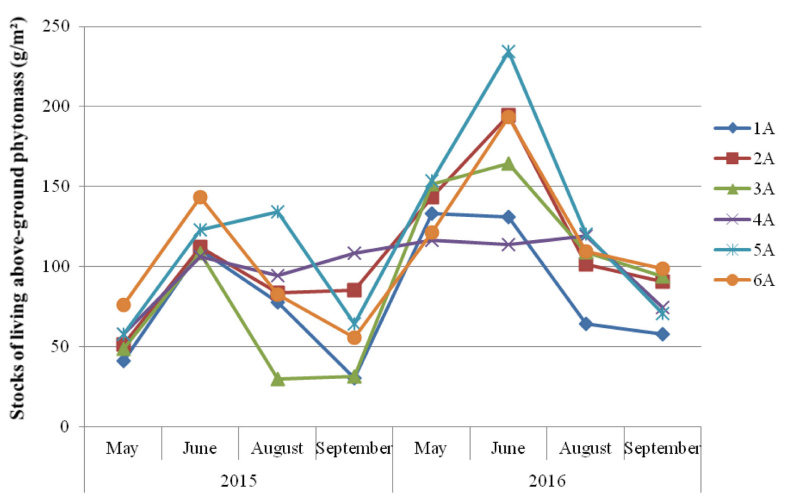

Fig. 6. Dynamics of the stock of the living phytomass on burnt plots. 
In the first post-fire year, the stock of the living phytomass on the burnt and unburnt plots had statistically significant differences on study sites №1, 3, 4. There were no differences found on study sites №2, 5, 6 (Table 2). Such a division of study sites into two groups suggests an interesting pattern associated with the characteristics of the original plant communities located on these sites. For study sites damaged by intensive use before the Protected Area foundation, we found statistically significant differences in the stock of the living phytomass between the burnt and unburnt plots, as follows: study sites №1, 3 were grazed, while study site №4 is an old abandoned field.

For the second post-fire year, the MannWhitney U-test showed no statistically significant differences between the stock of the living phytomass on the burnt and unburnt plots on any of the study sites. Consequently, the values of the living phytomass on burnt plots already reached the values of this parameter on unburnt plots by the second post-fire year. Thus, a decrease in the total stock of the above-ground phytomass $(\mathrm{G}+\mathrm{D}+\mathrm{L})$ in the first post-fire year is mainly explained by the loss and slower recovery of the dead phytomass $(\mathrm{D}+\mathrm{L})$.

\section{Stock of the living phytomass of grasses}

Both the living and dead above-ground phytomass of the firm-bunch grasses (Stipa zalesskii Wilensky, Stipa lessingiana Trin. \& Rupr., Festuca valesiaca Gaudin, Stipa capillata L.) dominated on the unburnt plots. On the burnt plots, grass species dominated in the first post-fire year. However, grasses can be inferior in the above-ground living phytomass to forbs or dwarf semi-shrubs.

The comparison of the stock of the living phytomass of grasses $\left(\mathrm{G}_{\mathrm{gr}}\right)$ on the study sites demonstrated statistically significant differences between burnt and unburnt plots only in the study sites managed earlier: 2015 - study sites №3, 4, in 2016 - study sites №1, 4 (Table 2). No differences were found on the other study sites. However, an increase in the projective cover of grasses up to the control values in the plant communities has not occurred yet.

On most of the burnt plots, the stock of the above-ground living phytomass of grasses reached the highest values by August of the first post-fire year. On the unburnt plots, a peak was in June during all the study years. Such a shift of peaks in the grass phytomass accumulation was a result of the direct fire effect on grass species. In the second post-fire year, we did not find such effect, and peaks were found in May - June 2016.

\section{Stock of the living phytomass of forbs}

The fire effect on different groups of the steppe plants is not uniform. After the fire impact, the grasses were in a depressed state, while the taproot perennial forbs increased both their abundance and stock of the living phytomass. Similarly, the abundance of the short-living species (including some weeds) increased on the burnt plots.

We did not find statistically significant differences for the stock of the living phytomass of forbs $\left(\mathrm{G}_{\text {for. }}\right)$ between the burnt and unburnt plots for a whole study period. Values of the stock of the living phytomass of forbs on burnt plots was close to values of this parameter on unburnt plots during the whole study period. This indicates the ability of forbs for a rapid post-fire recovery (Table 2). The maximum stock of the living phytomass of forbs on the unburnt plots was associated with June. On the burnt plot, the maximum stock has been also associated with June in the first post-fire year and with May in the second post-fire year. This is associated with a post-fire increase in the phytocoenotic role of the spring-flowering perennials (e.g. Scorzonera austriaca Willd., S. stricta Hornem., Potentilla humifusa Willd. ex Schltdl.), including ephemeroids (e.g. Tulipa biebersteiniana Schult. \& Schult. f., Allium tulipifolium Ledeb., Gagea pusilla (F.W. Schmidt) Schult. \& Schult. f.), and short-living species (e.g. Sisymbrium polymorphum (Murray) Roth, Androsace maxima L., Draba nemorosa L.). This is evidenced by their massive appearance after the fire impact in steppes. The summer-flowering species (e.g. Galium ruthenicum Willd., Eremogone biebersteinii (Schltdl.) Holub, Salvia stepposa Des.Shost., S. tesquicola Klokov \& Pobed.) dominated on the unburnt study plots.

\section{Stock of the living phytomass of dwarf semi-shrubs}

There were no statistically significant differences between the burnt and unburnt plots in the stock of the living phytomass of dwarf semi-shrubs $\left(\mathrm{G}_{\mathrm{dsh}}\right)$ during the whole study period (Table 2).

On both burnt and unburnt study plots, the phytomass values changed depending on the 
phenotypic rhythms of the dominant dwarf semishrub species. Because of the fact that among dwarf semi-shrubs, the summer-flowering species (e.g. Eremogone koriniana (Fisch. ex Fenzl) Ikonn., Onosma simplicissima L.) prevailed, the maximum of the stock of the living phytomass of dwarf semi-shrubs was in June (study site №5). Under prevalence of the late-flowering species (Artemisia austriaca Jacq., A. marschalliana Spreng.), the maximum stock was at the end of the vegetation period (study site №4). According to our data, some of the summer-flowering species remain green for a long time and can represent a significant part of the stock of the living phytomass in August and September. Sedges and shrubs are characterised by a small coenotic role and a small contribution in the formation of the stock of the living phytomass during the entire study period.

\section{Stock of dead phytomass}

During the 2014 fire, the entire above-ground dead phytomass $(\mathrm{D}+\mathrm{L})$ burnt out on the burnt plots. The soil became bare, and the newly forming dead phytomass partially deflated under wind influence. The stock of the dead phytomass on the unburnt plots exceeded the stock on the burnt plots by $3.5-31$ times (in some cases, it was by several hundreds or even thousands times) in 2015 , and by $2-9$ times in 2016 .

During the entire study period on all study sites, the stock of the above-ground dead phytomass on unburnt plots was higher than on burnt plots. Statistically significant differences in the above-ground dead phytomass stocks between burnt and unburnt plots were found during the whole study period on all study sites (Table 2). In the first post-fire year, the stock of the above-ground dead phytomass on the burnt plots gradually increased on all study sites from May to September. The maximum stock was associated with September in both burnt and unburnt plots. In the second post-fire year, the maximum stock was typical for August on both burnt and unburnt plots.

During the whole study period, the stock of the standing dead phytomass dominated in the structure of the stock of the dead phytomass on the burnt plots. On the unburnt plots, there were two variants of the stock of the dead phytomass distribution. On study sites №1, 3, 5, the litter phytomass dominated under standing dead phytomass during the whole study period. On study sites №2,
4, 6, the litter phytomass prevailed at the beginning and end of the vegetation period, i.e. at the time once the standing dead phytomass intensively transferred to litter phytomass.

The seasonal dynamics of the stock of the standing dead phytomass and litter differed in the study years by following the seasonal characteristics of changes in the living phytomass and its components.

\section{Stock of the standing dead phytomass}

In all study years, the stock of the standing dead phytomass was higher on unburnt plots of all study sites. In the first post-fire year, it was by 1.5 50 times (in some cases, by hundreds times) higher, in the second post-fire year, it was 1.3-4 times higher. The comparison of the stock of the dead standing phytomass on burnt and unburnt plots showed statistically significant differences using the Mann-Whitney U-test $(\alpha<0.05)$. It was typical for the whole study period (Table 2). Herbaceous plants of different life forms differed by processes of death of certain organs, their subsequent preservation, subsequent decomposition and destruction.

\section{Stock of the standing dead phytomass of grasses}

During the whole study period, the stock of the standing dead phytomass of grasses on the unburnt study plots differed significantly from the one on the burnt plots on all study sites (Table 2 ). We identified two peaks of an increase in the stock of the standing dead phytomass of grasses, associated with spring and late summer periods. These peaks were more expressed on the unburnt plots. On unburnt plots, the first (spring or early summer) peak of the stock of the standing dead phytomass is determined by leaves of grasses preserved during the winter after the previous autumn generation. The second peak is associated with the dried leaves of the spring generation of the current year (Fig. 7). On burnt plots, we found a peak of the stock of the standing dead phytomass dated in the late summer of 2015 and in the early summer in 2016 (Fig. 8).

\section{Stock of the standing dead phytomass of forbs}

In the steppe plant communities, there are species of forbs of different types of phenological rhythms (Borisova, 1965; Borisova \& Popova, 1972; Semenova-Tyan-Shanskaya, 1977). Differences in occurrence of these species groups on burnt and unburnt plots determine the dynamics of the stock of the living phytomass of forbs and its transition to the stock of the standing dead phytomass. 


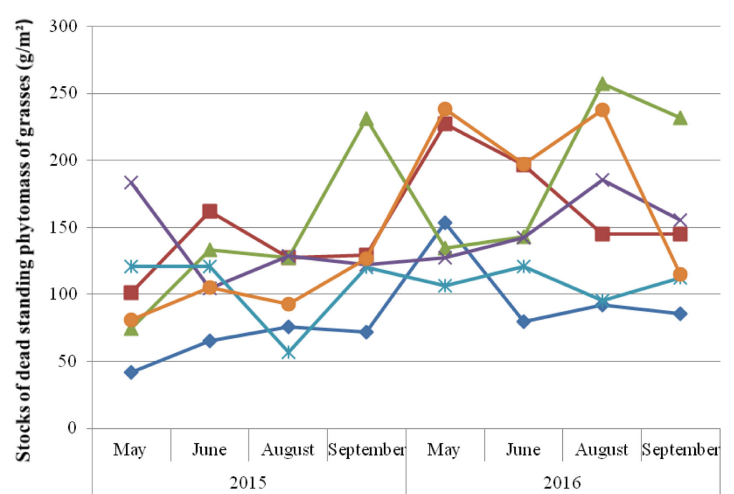

Fig. 7. Dynamics of the stock of the standing dead phytomass of grasses on unburnt plots.

We compared burnt and unburnt plots for the stock of the standing dead phytomass of forbs using the Mann-Whitney U-test, and showed statistically significant differences on study sites №5, 6 in 2015 and on the study sites №2, 5 in 2016. On these study sites, the abundance of Galatella villosa (L.) Rchb. f., Galium octonarium (Klokov) Soó, Galium ruthenicum was remarkably higher on the unburnt plots than on the burnt ones. At the same time, on the burnt plots, the stock of the standing dead phytomass of forbs was also formed by the spring-flowering and short-lived species. These species rapidly finished flowering and turned into the standing dead phytomass with rapid transition into litter. Both on the unburnt and burnt plots, the maximum stock of the standing dead phytomass of forbs has been found by the late vegetation period.

Stock of the standing dead phytomass of dwarf semi-shrubs

Both on the unburnt and burnt plots, there was a small accumulation of the stock of the standing dead phytomass of dwarf semi-shrubs. By the late vegetation period, its amount was growing on both burnt and unburnt plots.

We compared burnt and unburnt plots for the stock of the standing dead phytomass of dwarf semishrubs using the Mann-Whitney U-test, and showed statistically significant differences on study sites №1, 6 in 2015 and on study site №2 in 2016. In these cases, the stock of the standing dead phytomass was higher on the unburnt plots than on the burnt ones (Table 2 ). This is explained by the fact that after the fire impact, on study sites №1, 6, Artemisia marschalliana disappeared in the plant communities, while Astragalus macropus reduced its abundance compared to the unburnt plots. In 2016, there were no significant differences in the abundance of dwarf semi-shrubs between the burnt and unburnt plots on study site №2.

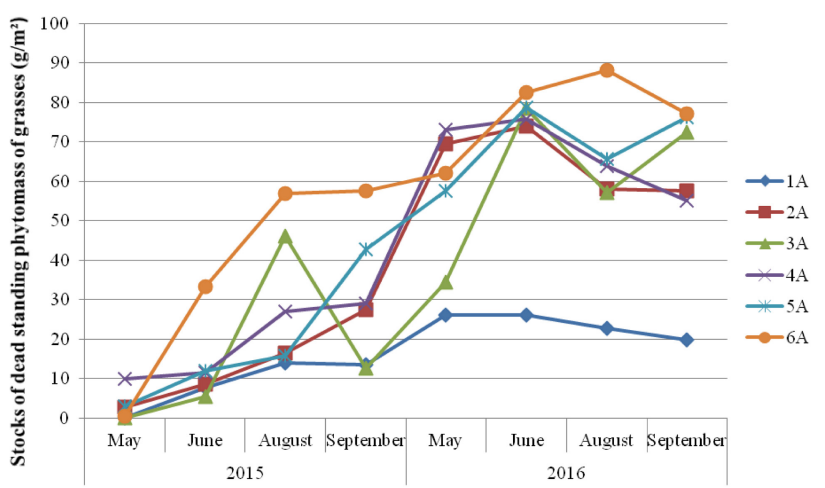

Fig. 8. Dynamics of the stock of the standing dead phytomass of grasses on burnt plots.

The differences are probably associated with uneven distribution of dwarf semi-shrubs within a study plot.

\section{Stock of litter}

After the 2014 fire, the litter completely burnt out on the study plots. In May and August 2015, there was no litter on burnt plots, possibly due to the wind affect. From 2015 to 2016, the amount of the stock of litter increased by 1.5-4.0 times on the burnt plots, while on the unburnt plots the increase was 1.2-3.0 times. On the unburnt plots, the stock of litter was higher than on the burnt ones by 4-25 times in 2015, and by $2-15$ times in 2016. In all study years, the amount of the stock of litter differed statistically significantly between burnt and unburnt plots on each study site (Table 2).

On the study sites, the litter decomposed from April to June. The most favourable weather conditions for the transition of the litter into the soil were in May - June. This process actively took place on the unburnt plots (Fig. 9). On the burnt plots, the litter amount was minimal. Its unburnt residues represented most of the stock of litter (Fig. 10).

From mid- to late summer, the litter decomposition slowed down on the study sites due to a sharp increase in the air temperature $\left(30-32^{\circ} \mathrm{C}\right)$ with a relative air humidity much lower than the norm (Table 1). In August, we found the maximum stock of the litter on some study plots. It concerned only unburnt plots, as on the burnt plots, the litter was almost absent due to the wind affect.

In September, we found a decrease in the stock of the litter on the unburnt study sites №3, 4, 6, indicating a continuation of the litter destruction. On other study sites, the litter accumulation continued, which may be explained by the small total monthly precipitation amount $(14.5 \mathrm{~mm})$ during this period. On the burnt plots, the stock of the litter continued to accumulate (Fig. 10). 


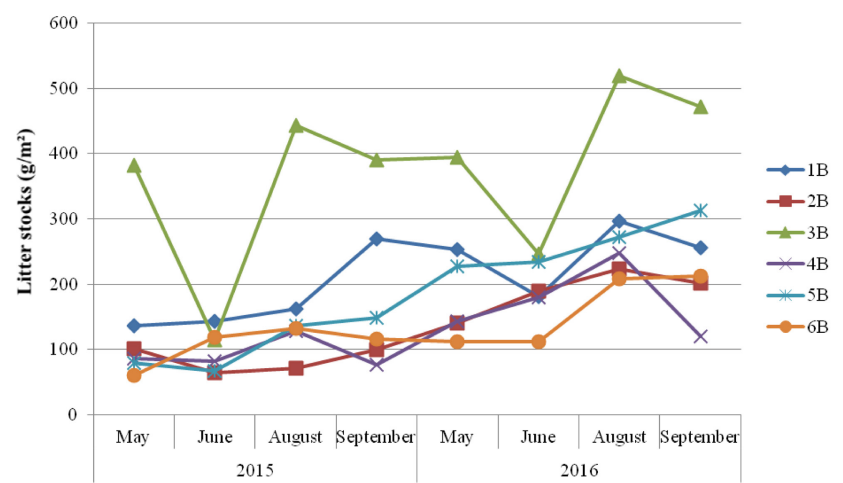

Fig. 9. Dynamics of the stock of the litter on unburnt plots.

From September 2015 to May 2016, on most of both burnt and unburnt study plots, the stock of the litter increased. Despite the temperature and humidity (Table 1) being favourable for the litter decomposition, the stock of litter continued to increase on the unburnt plots of study sites №2, 4, 5, 6. On the other hand, on study sites №1, 3, there was a sharp transition of litter into the soil.

The dead phytomass accumulated on most of the burnt plots. From June to August, both on the burnt and unburnt plots, the litter mass increased on all study sites. In September, the decrease in the average monthly temperature and the increase in the total monthly amount of precipitation affected the litter mass decrease on both burning and control plots.

\section{Discussion}

We revealed some features of the post-fire dynamics of the stock of the above-ground phytomass in the steppe plant communities in the study area. For appropriate comparison of our data with analogous studies conducted earlier, geographic locations of compared sites should be taken into account. The patterns of fire influence on the vegetation cover of grasslands are mainly specific and determined by the zonal position of the study area. Therefore, our data are less comparable with data of foreign studies. It is predominantly explained by differences in seasonal dynamics and composition and patterns of phytomass stock. The results of our research are most comparable with studies conducted in Russia and adjacent countries (e.g. Ukraine, Kazakhstan).

The interpretation of both obtained data and post-fire patterns is also influenced by the views of different specialists on the ecosystem role of a vegetation cover. The same reasons determine the difference in the obtained results and their assessments in different regions, in the formation of ideas

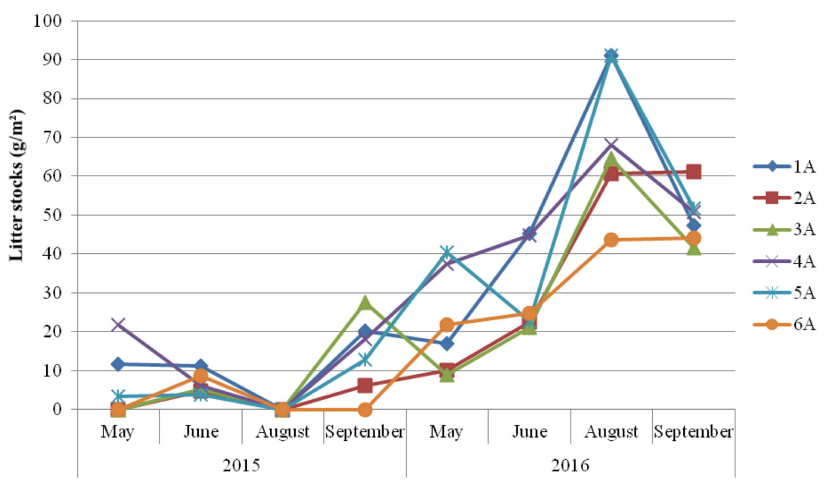

Fig. 10. Dynamics of the stock of the litter on burnt plots.

on importance of the fire factor in the dynamics of the steppe ecosystems as a whole.

As a result of our conducted research, we showed a post-fire decrease in the stock of the above-ground phytomass, determined primarily by a decrease in the stock of the standing dead phytomass and litter, in accordance to previous studies (RozhanetsKucherovskaya, 1926; Ryabinina, 2014; Martynova, 2016). Similar data were obtained in Mongolia (Tuvshintogtokh \& Magsar, 2000, 2007), Turkey (Gullap et al., 2018), Ukraine (Gavrilenko, 2008), USA (Old, 1969; Davies et al., 2007).

At the same time, a number of authors believe that fire has no significant impact on the aboveground phytomass or even leads to its increase. For example, data from North America (Augustine \& Milchunas, 2009; Augustine et al., 2010) and Europe (Valkó et al., 2014, 2016) did not note a decrease in the above-ground phytomass at the burnt areas. However, Valkó et al. (2016) indicated extensive grazing or mowing as one of the causes explaining these results. Thus, a significant part of the dead phytomass is destroyed during such exploitation types. And the stock of the standing dead phytomass and litter becomes equally low both on the burnt and unburnt plots.

Our data indicate a rapid post-fire recovery of the stock of the living phytomass until the values on unburnt plots. Many authors indicated also an increase in the stock of the living phytomass on burnt plots in comparison with unburnt areas (e.g. Dhillion \& Anderson, 1994; Yunusbayev \& Abdulina, 2010; Pereira et al., 2015; Valkó et al., 2016). However, long-term studies (e.g. Titlyanova \& Sambuu, 2016) showed an increase in the stock of the living phytomass in the first post-fire period and its gradual decrease in the following years.

Steppe plant communities are characterised by a post-fire decrease in the litter stock and its gradual accumulation during the following years. In ac- 
cordance with that, some authors consider the reduction of the litter stock as a positive fire effect on the vegetation cover of steppes and their analogues (e.g. Hansson \& Fogelfors, 2000; Antonsen \& Olsson, 2005; Deák et al., 2014). However, we believe that the litter is a necessary and mandatory component of any steppe plant community. The stock of litter is determined by the need for the formation and regulation of the microclimate within the plant community under the current weather conditions.

The fire effect on different groups of steppe plants is not uniform. It depends largely on the zonal position of the study area and its environmental patterns. In the plant communities we studied, grasses dominated. These plants were the most affected group within the plant community in accordance with data of other authors (e.g. Danilov, 1936; Ivanov, 1952; Borisova \& Popova, 1972; Ryabinina, 2014; Tkachuk \& Denisova, 2015).

While we demonstrated the fire effect on the stock of the living phytomass of grasses only for separate study sites, we found that the stock of the dead phytomass of grasses determined differences in values and dynamics compared to the stock of the total phytomass on all study sites during the whole study period. The rapid restoration of the stock of the living phytomass of grasses on burnt plots until the level of unburnt plots is explained by the location of their buds below the fire-damaged soil surface (Shalyt \& Kalmykova, 1935; Tanfilyev, 1936). At the same time, despite the ability of a rapid restore of the stock of the living phytomass, the stock of the dead phytomass of grass-based plant communities is significantly affected by fire and the recovery takes longer.

We have shown that the stock of the living phytomass of forbs and dwarf semi-shrubs on burnt plots rapidly reached its level on unburnt plots. For the stock of the living phytomass of forbs, it is explained by an increase a role of weeds, ephemeroids, annuals and some biennials. A post-fire increase in the forbs species richness was noted also by Allan et al. (2003), Bates et al. (2009), Twidwell et al. (2012), Winter et al. (2013, 2015), Kertész et al. (2017). Danilov (1936), Fedyunkin (1953) noted an increase in the role of the forbs in the burnt plant communities.

During the vegetation season, both the stock of the above-ground phytomass and its dynamics changed under the fire influence. In this case, we found a shift in the peaks of accumulation of certain components of the above-ground phytomass on the burnt plots in comparison to the unburnt plots. The values and number of such peaks also changed.

The seasonal changes in the plant community are determined by the development of certain plants, where phenological rhythms of dominant species play a primary role (Borisova, 1976). We have shown (Fig. 2, 6, 9) that unburnt plots are characterised by more diverse seasonal dynamics of the above-ground phytomass and its components, depending on the floristic composition, ecological preferences of species and the conditions of the vegetation period. On the burnt plots, the seasonal dynamics of the stock of the above-ground phytomass was less diverse. It was predominantly similar for different study plots, and often remarkably different from the unburnt plots.

\section{Conclusions}

After the fire influence on the steppe vegetation, a serious transformation of the plant community takes place. During all study years, the total post-fire stock of the above-ground phytomass on all study plots was lower than on the unburnt plots. On the burnt plots, the stock of phytomass accumulated in the spring and early summer. The living phytomass had the highest contribution to the formation of the above-ground phytomass stock. On the unburnt plots, its accumulation occurred in the late summer and autumn with the highest role of the dead phytomass. The stock of the living phytomass reached the values of unburnt plots at the first post-fire year, if the sites had not been managed previously. If the burnt plots had been overgrazed or were represented by abandoned lands, the stock of the living phytomass reached the values of unburnt plots at the second post-fire year. During the whole study period, no statistically significant differences in the stock of the living phytomass of forbs and dwarf semi-shrubs were found between burnt and unburnt plots. For the stock of the living phytomass of grasses, these differences were found on the study sites №1, 3, 4 . The stock of dead phytomass exceeded the stock of the living phytomass on the unburnt plots during the whole vegetation season, while on the burnt plots, we observed it only by the end of the vegetation period. During the whole study period, the stocks of the dead phytomass, standing dead phytomass, and litter, standing dead phytomass of grasses were higher on the unburnt plots than on the burnt ones on all study plots. The stock of the standing dead phytomass predominated in the dead phytomass structure of the burnt plots, while the stock of litter prevailed on unburnt plots. 
In conclusion, we have shown that only stock of the living phytomass and its components (grasses, herbs, dwarf semi-shrubs) are able to restore in the first two post-fire years. The remaining fractions of the above-ground phytomass do not reach the values observed in unburnt plots.

\section{Acknowledgments}

The article was prepared within the framework of budget of the theme of the Institute of steppe UB RAS No. GR AAAA-A17-117012610022-5. During the investigations, the post-fire monitoring in the site «Burtinskaya steppe» was supported by the Ministry of Natural Recourses and Environment of Russia «Improving the system and mechanisms for managing Protected Areas in the steppe biome of Russia».

\section{References}

Allan G.E., Phillips N.R., Hookey P. 2003. Learning lessons from an exceptional period of fires in Central Australia: 1999 to 2002. In: Proceedings of the $3^{\text {rd }}$ International Wildland Fire Conference (3-6 October 2003, Sydney). Sydney. Paper 163. (CD-ROM).

Andersen A.N., Cook G.D., Corbett L.K., Douglas M.M., Eager R.W., Russell-Smith J., Setterfield S.A., Williams R.J., Woinarski J.C.Z. 2008. Fire frequency and biodiversity conservation in Australian tropical savannas: implications from the Kapalga fire experiment. Austral Ecology 30(2): 155-167. DOI: 10.1111/j.14429993.2005.01441.x

Antonsen H., Olsson P.A. 2005. Relative importance of burning, mowing and species translocation in the restoration of a former boreal hayfield: responses of plant diversity and the microbial community. Journal of Applied Ecology 42(2): 337-347. DOI: 10.1111/j.13652664.2005.01023.x

Augustine D.J., Milchunas D.G. 2009. Vegetation responses to prescribed burning of grazed shortgrass steppe. Rangeland Ecology and Management 62(1): 89-97. DOI: $10.2111 / 08-135$

Augustine D.J., Derner J.D., Milchunas D.G. 2010. Prescribed fire, grazing, and herbaceous plant production in shortgrass steppe. Rangeland Ecology and Management 63(3): 317-323. DOI: 10.2111/REM-D-09-00044.1

Bates J.D., Rhodes E., Davies K., Sharp R. 2009. Postfire succession in big sagebrush steppe with livestock grazing. Rangeland Ecology and Management 62(1): 98110. DOI: $10.2111 / 08-096$

Bazilevich N.I., Titlyanova A.A., Smirnov V.V., Rodin L.E., Nechaeva N.I., Levin F.I. 1978. Methods of studying the biological cycle in various natural zones. Moscow: Mysl. 185 p. [In Russian]

Borisova I.V. 1965. Rhythms of seasonal development of steppe plants and zonal types of steppe vegetation of Central Kazakhstan. In: Biology and ecology of plants of virgin areas of Kazakhstan. Moscow; Leningrad: Nauka. P. 64-100. [In Russian]

Borisova I.V. 1976. Phenological development of plants. In: Bio-complex research in Kazakhstan. Part 3. Complex characteristics of the main plant communities of the desert steppes of Central Kazakhstan. Leningrad: Nauka. P. 40-50. [In Russian]

Borisova I.V., Popova T.A. 1972. Dynamics of number and age composition of cenopopulations of bunch grasses in desert steppes of Central Kazakhstan. Botanicheskii Zhurnal 7: 779-793. [In Russian]

Chibilev A.A. 1996. Steppe Reserve «Orenburg»: physicalgeographical and ecological characteristics. Ekaterinburg: Publishing house of the Ural Branch of RAS. 167 p. [In Russian]

Danilov S.I. 1936. Fire in the Transbaikalian steppes and its influence on vegetation. Vestnik of the Far Eastern Branch of AS USSR 21: 63-81. [In Russian]

Davies K.W., Bates J.D., Miller R.F. 2007. Short-Term Effects of Burning Wyoming Big Sagebrush Steppe in Southeast Oregon. Rangeland Ecology and Management 60(5): 515-522. DOI: 10.2111/1551-5028(2007)60[515:SEO BWB]2.0.CO;2

Davies K.W., Svejcar T.J., Bates J.D. 2008. Influence of long-term livestock grazing exclusion on the response of sagebrush steppe plant communities to fire. In: Oregonstate.edu. Available from https://oregonstate.edu/ dept/eoarc/sites/default/files/publication/604.pdf

Davies G.M., Bakker J.D., Dettweiler-Robinson E., Dunwiddie P.W., Hall S.A., Downs J., Evans J. 2012. Trajectories of change in sagebrush steppe vegetation communities in relation to multiple wildfires. Ecological Applications 22(5): 1562-1577. DOI: 10.1890/10-2089.1

Davies K.W., Gearhart A., Boyd C.S., Bates J.D. 2017. Fall and spring grazing influence fire ignitability and initial spread in shrub steppe communities. International Journal of Wildland Fire 26(6): 485-490. DOI: 10.1071/WF17065

Deák B., Valkó O., Schmotzer A., Kapocsi I., Tóthmérész B., Török P. 2012. Grassland burning in Hungary - is it a problem or a promising conservation measure? Journal of Landscape Ecology 10(2): 287-303.

Deák B., Valkó O., Török P., Végvári Zs., Hartel T., Schmotzer A., Kapocsi I., Tóthmérész B. 2014. Grassland fires in Hungary - experiences of nature conservationists on the effects of fire on biodiversity. Applied Ecology and Environmental Research 12(1): 267-283. DOI: 10.15666/ aeer/1201_267283

Dhillion S.S., Anderson R.C. 1994. Production on burned and unburned sand prairies during drought and nondrought years. Vegetatio 115(1): 51-59. DOI: 10.1007/ BF00119386

Dickson T.L., Hayes B.A., Bragg T.B. 2018. Effects of 34 Years of Experimentally Manipulated Burn Seasons and Frequencies on Prairie Plant Composition. Range- 
land Ecology and Management 72(1): 82-91. DOI: 10.1016/j.rama.2018.07.014

Drohobych N.E. 2000. Post-pyrogenic dynamics of the aboveground phytomass of the steppe phytocenoses of the Black Sea region In: A.A. Chibilev (Ed.): Steppes of Northern Eurasia: a strategy for the conservation of natural diversity and steppe environmental management in the XXI century. Orenburg: PPC «Gazprompechat». P. 148-150. [In Russian]

Dubinin M.Yu., Lushchekina A.A., Radeloff F.K. 2011. Assessment of the present dynamics of fires in arid ecosystems by use of remote sensing data: The case of chernye zemli. Arid ecosystems 1: 184-192. DOI: 10.1134/ S2079096111030061

Dufek N.A., Augustine D.J., Blumenthal D.M., Kray J.A., Derner J.D. 2018. Dormant-Season Fire Inhibits Sixweeks Fescue and Enhances Forage Production in Shortgrass Steppe. Fire Ecology 14(1): 33-49. DOI: 10.4996/fireecology.140132048

Engle D.M., Bidwell T.G., Ewing A.L., Williams J.R. 1989. A technique for quantifying fire behavior in grassland fire ecology studies. The Southwestern Naturalist 34(1): 79-84. DOI: $10.2307 / 3671812$

Fedyunkin D.F. 1953. Impact of dead plant debris and steppe fires on the development of vegetation in forest-steppe Transural. Izvestiya Yestestvenno-Nauchnogo Instituta pri Molotovskom gosudarstvennom universitetete imeni A.M. Gorkogo 7: 621-639. [In Russian]

Fuhlendorf S.D., Engle D.M. 2001. Restoring heterogeneity on rangelands: ecosystem management based on evolutionary grazing patterns. Bioscience 51(8): 625632. DOI: 10.1641/0006-3568(2001)051[0625:RHOR EM]2.0.CO;2

Fuhlendorf S.D., Engle D.M. 2004. Application of the firegrazing interaction to restore a shifting mosaic on tallgrass prairie. Journal of Applied Ecology 41(4): 604 614. DOI: 10.1111/j.0021-8901.2004.00937.x

Gavrilenko V.S. 2008. Modern regimes of the reserved steppe of «Askania-Nova» and some results of their influence on the conservation of biodiversity. Nature Reserves in Ukraine 1: 53-61. [In Russian]

Gullap M.K., Erkovan S., Erkovan H.I., Koc A. 2018. Effects of fire on litter, forage dry matter production, and forage quality in steppe vegetation of Eastern Anatolia, Turkey. Journal of Agricultural Science and Technology 20(1): 61-70.

Hansson M., Fogelfors H. 2000. Management of a semi-natural grassland; results from a 15-year-old experiment in southern Sweden. Journal of Vegetation Science 11(1): 31-38. DOI: $10.2307 / 3236772$

Hoffman O.P. 2015. Age structure of Festuca valesiaca s.1. (Poaceae) under the influence of pyrogenic and patscale factors in the Biosphere Reserve «Askania-Nova». In: A.A. Chibilev (Ed.): Steppes of Northern Eurasia: Materials of the VII International Symposium. Orenburg: PH «Dimur». P. 270-272. [In Russian]
Ilyina V.N. 2011. Pyrogenic effect on vegetation cover. Samarskaya Luka: problems of regional and global ecology 2: 4-30. [In Russian]

Ivanov V.V. 1952. On the question of the role of the steppe fires. Bulletin of the Moscow Society of Naturalists 1: 62-69. [In Russian]

Kalmykova O.G. 2006. Factors determining the diversity and features of the vegetation cover of the Burtinskaya steppe. In: A.A. Chibilev (Ed.): Steppes of Northern Eurasia: Proceedings of the IV International Symposium. Orenburg: IPK «Gazprompechat»; LLC «Orenburggazpromservis». P. 333-337. [In Russian]

Kalmykova O.G. 2009. Features of plant communities of the Stipeta lessingianae formation in the Burtinsky steppe. In: A.M. Rusanov (Ed.): Materials of the IV All-Russian Scientific and Practical Conference "Problems of the Ecology of the Southern Urals». Orenburg: OSU. P. 266-268. [In Russian]

Kalmykova O.G. 2012. Features of plant communities of the Stipeta zalesskii formation in the Burtinskaya steppe (Orenburg State Nature Reserve). In: A.A. Chibilev (Ed.): Steppes of Northern Eurasia: Proceedings of the VI International Symposium. Orenburg: IPK «Gazprompechat»; LLC «Orenburggazpromservis». P. 349352. [In Russian]

Kandalova T.G. 2007. The influence of the steppe fires on the real and meadow steppes of the State Reserve «Khakassky». Steppe Bulletin 23-24: 19-24. [In Russian]

Kertész M., Aszalós R., Lengyel A., Ónodi G. 2017. Synergistic effects of the components of global change: Increased vegetation dynamics in open, forest-steppe grasslands driven by wildfires and year-to-year precipitation differences. PLoS ONE 12(11): e0188260. DOI: 10.1371/journal.pone.0188260

Kudryavtsev A.Yu. 2016. The impact of fires on the ecosystems of the Poperechenskaya Steppe. In: O.N. Leonova (Ed.): Modern concepts of ecology of biosystems and their role in solving problems of nature conservation and nature management: Materials of the AllRussian (with international participation) scientific school-conference dedicated to the $115^{\text {th }}$ anniversary of A.A. Uranov. Penza: Penza State University. P. 242 244. [In Russian]

Lavrenko E.M. 1950. Some observations on the influence of fire on the vegetation of the northern steppe (Poperechenskaya steppe of the Penza region). Botanicheskii Zhurnal 1: 77-78. [In Russian]

Lavrenko E.M., Korchagin A.A. 1964. Field geobotany. Vol. 3. Moscow: Publishing house of AS USSR. 530 p. [In Russian]

Lavrenko E.M., Korchagin A.A. 1972. Field geobotany. Vol. 4. Leningrad: Nauka. 330 p. [In Russian]

Lysenko G.N. 2006. Stability of steppe phytocoenostructures: thermodynamic aspect. In: A.A. Chibilev (Ed.): Steppes of Northern Eurasia: Materials of the IV In- 
ternational Symposium. Orenburg: PPC «Gazprompechat»; LLC «Orenburggazpromservis». P. 449-451. [In Russian]

Martynova L.V. 2016. Comparative assessment of the impact of pyrogenic factors on vegetation cover of the steppe zone. Bulletin of KrasGAU 6: 112-119. [In Russian]

Mata-González R., Reed-Dustin C.M., Rodhouse T.J. 2018. Contrasting effects of long-term fire on sagebrush steppe shrubs mediated by topography and plant community. Rangeland Ecology and Management 71(3): 336-344. DOI: 10.1016/j.rama.2017.12.007

Ogureyeva G.N. 1999. Zones and types of Vertical zones of vegetation in Russia and adjacent territories. Map for higher education institutions. Scale 1 : 8000 000. Moscow: Integratsiya. 2 p. [In Russian]

Old S.M. 1969. Microclimate, fire and plant production in an Illinois prairie. Ecological Monographs 39(4): 355 384. DOI: $10.2307 / 1942353$

Pavleichik V.M. 2015. Spatial-temporal structure of fires in the reserved area «Burtinskaya Steppe». Bulletin of the Orenburg Scientific Centre of the Ural Branch of RAS 4: 1-12. [In Russian]

Pavleichik V.M. 2016. Long-term dynamics of natural fires in the steppe regions (by the example of the Orenburg region). Bulletin of the Orenburg State University 6(194): 74-80. [In Russian]

Pavleichik V.M., Kalmykova O.G., Soroka O.V. 2016. Features of the microclimatic regime of steppe fires on the reserved site «Burtinskaya steppe». Samarskaya Luka: problems of regional ecology 4: 69-74. [In Russian]

Pereira P., Cerda A., Lopez A.J., Zavala L.M., Mataix-Solera J., Arcenegui V., Misiune I., Keesstra S., Novara A. 2015. Vegetation recovery after a grassland fire in Lithuania. The effects of fire severity, slope position and aspect. Land Degradation and Development 27(5): 1523-1534. DOI: 10.1002/ldr.2498

Pereira P., Mierauskas P., Novara A. 2016. Stakeholders' perceptions about fire impacts on Lithuanian protected areas. Land Degradation and Development 27(4): 871883. DOI: $10.1002 / 1 \mathrm{dr} .2290$

Pereira P., Francos M., Ubeda X. Brevik E.C. 2017. Fire impacts in European grassland ecosystems. In: Antynio Josй Bento-Gonzalves (Ed.): Wildfires: Perspectives, Issues and Challenges of the $21^{\text {st }}$ Century. Hauppauge, NY: Nova Science Publishers. P. 1-28.

Rabotnov T.A. 1992. Phytocenology. Moscow: Moscow State University Press. 350 p. [In Russian]

Rostagno C.M., Defossé G.E., del Valle H.F. 2006. Postfire vegetation dynamics in three rangelands of northeastern Patagonia, Argentina. Rangeland Ecology and Management 59(2): 163-170. DOI: 10.2111/05-020R1.1

Rozhanets-Kucherovskaya S.E. 1926. Report on the vegetation of the Orenburg province. Orenburg: $5^{\text {th }}$ Hostip. Polygraphist. 16 p. [In Russian]

Ruprecht E., Enyedi M.Z., Szabó A., Fenesi A. 2016. Biomass removal by clipping and raking vs burning for the restoration of abandoned Stipa-dominated European steppe-like grassland. Applied Vegetation Science 19(1): 78-88. DOI: 10.1111/avsc.12199

Ryabinina Z.N. 2003. Vegetation cover of the steppes of the Southern Urals (Orenburg region). Orenburg: Publishing house OGPU. 224 p. [In Russian]

Ryabinina N.O. 2013. Natural and anthropogenic factors of variability in the dynamics of the bio-productivity of the geosystems of the virgin bunchgrass steppes of the Eastern Don Ridge. Journal of Volgograd State University. Natural sciences 2: 62-67. [In Russian]

Ryabinina N.O. 2014. The impact of fires on the steppe landscapes of the Eastern-Don Ridge. In: S.N. Kanishchev (Ed.): Anthropogenic transformation of geospace: history and modernity: Materials of AllRussian scientific-practical conference. Volgograd: Publishing House of Volgograd State University. P. 41-48. [In Russian]

Ryabinina Z.N., Yanturin S.I., Ryabtsov S.N., Abdulina K.Kh., Yunusbayev U.B. 2010. The role of steppe fires in the formation of vegetation cover of the Southern Urals. Ufa: Academy of Sciences of Bashkortostan; Gilem. 219 p. [In Russian]

Ryabtsov S.N. 2002. On the question of the history of the study of the restoration of steppe vegetation after pyrogenic loading. In: Z.N. Ryabinina (Ed.): Biodiversity and Bioresources of the Urals and Adjacent Territories: Proceedings of the II International conference. Orenburg: Publishing house of the OGPU. P. 106-107. [In Russian]

Ryabtsov S.N. 2006. Dynamics of the structure of plant communities under the influence of fire. In: Z.N. Ryabinina (Ed.): Biodiversity and Bioresources of the Urals and Adjacent Territories: Proceedings of the III International scientific conference. Orenburg: Printservice. P. 101-103. [In Russian]

Ryabtsov S.N., Safonov M.A. 2002. Influence of pyrogenic load on steppe vegetation. Proceedings of the Institute of bioresources and applied ecology 2: 41-42. [In Russian]

Safronova I.N., Kalmykova O.G. 2012. Zonality issues and the role of reserves in their solution. Proceedings of Samara Scientific Centre RAS 1(6): 1638-1641. [In Russian]

Sambuu A.D., Dapyldai A.D. 2016. Fires of steppe vegetation on the territory of Tuva and their consequences. In: A.D. Sambuu (Ed.): Preservation of the diversity of flora in Tuva and adjacent regions of Central Asia: history, modernity, prospects: Materials of the $1^{\text {st }}$ International Scientific and Practical Conference. Kyzyl: Tuvikopr SB RAS. P. 135-141. [In Russian]

Scheintaub M.R., Derner J.D., Kelly E.F., Knapp A.K. 2009. Response of the shortgrass steppe plant community to fire. Journal of Arid Environments 73(12): 1136-1143. DOI: 10.1016/j.jaridenv.2009.05.011 
Semenova-Tyan-Shanskaya A.M. 1977. Accumulation and role of litter in grass communities. Leningrad: Nauka. 191 p. [In Russian]

Shalyt M.S., Kalmykova A.A. 1935. Steppe fires and their influence on vegetation. Botanicheskii Zhurnal 1: 101110. [In Russian]

Skolzneva L.N., Skolznev N.Ya. 2003. Some issues of protection of steppe ecosystems. In: A.A. Chibilev (Ed.): Steppes of Northern Eurasia. Reference steppe landscapes: problems of protection, ecological restoration and use: Proceedings of the III International Symposium. Orenburg: PPC Gazprompechat; LLC Orenburggazpromservis. P. 479-482. [In Russian]

Tanfilyev V.G. 1936. Experiments on the burning of old dry grass in a steppe zones. Sovetskaya Botanika 6: 82-88. [In Russian]

Timoshenkov V.A., Timoshenkova V.V. 2007. Fires in the Khomutovskaya steppe: causes, information, consequences. Steppe Bulletin 23-24: 27-30. [In Russian]

Tishkov A.A. 2003. Fires in the steppes and savannas. In: A.A. Chibilev (Ed.): Proceedings of the III international Symposium "Steppes of Northern Eurasia». Orenburg: PPC «Gazprompechat»; LLC «Orenburggazprom». P. 9-22. [In Russian]

Titlyanova A.A., Sambuu A.D. 2016. Successions in herbal ecosystems. Novosibirsk: Publishing House of the SB RAS. 191 p. [In Russian]

Tkachuk T.E. 2015. Multi-year dynamics of the steppe fires in Dauria. Fundamental Research 2-10: 2185-2189. [In Russian]

Tkachuk T.E., Denisova Yu.Yu. 2015. The influence of experimental burning on the structure of steppe phytocenoses in the south of Dauria. In: A.A. Chibilev (Ed.): Steppes of Northern Eurasia. Proceedings of the VII International Symposium. Orenburg: PH «Dimur». P. 847-849. [In Russian]

Tuvshintogtokh I., Magsar U. 2000. The effect of fires on plant society of steppe Eastern Mongolia. In: Academia.edu. Available from https://www.academia.edu/17187658/ THE EFFECT OF FIRES ON PLANT SOCIETY OF STEPPE EASTERN MONGOLIA 2000 ?auto=download

Tuvshintogtokh I., Magsar U. 2007. Fire Effects on Productivity and Community Dynamics of Mongolian Grasslands. International Forest Fire News (IFFN) 36: 67-75.
Twidwell D., Rogers W.E., McMahon E.A., Thomas B.R., Kreuter U.P., Blankenship T.L. 2012. Prescribed extreme fire effects on richness and invasion in coastal Prairie. Invasive Plant Science and Management 5(3): 330-340. DOI: 10.1614/IPSM-D-12-00017.1

Valkó O., Török P., Deák B., Tóthmérész B. 2014. Review: Prospects and limitations of prescribed burning as a management tool in European grasslands. Basic and Applied Ecology 15(1): 26-33. DOI: 10.1016/j.baae.2013.11.002

Valkó O., Deák B., Magura T., Török P., Kelemen A., Tóth K., Horváth R., Nagy D.D., Debnár Z., Zsigrai G., Kapocsi I., Tóthmérész B. 2016. Supporting biodiversity by prescribed burning in grasslands - a multi-taxa approach. Science of the Total Environment 572: 1377 1384. DOI: $10.1016 /$ j.scitotenv.2016.01.184

Valkó O., Kelemen A., Miglécz T., Török P., Deák B., Tóth K., Tóth J.P., Tóthmérész B. 2017. Litter removal does not compensate detrimental fire effects on biodiversity in regularly burned semi-natural grasslands. Science of the Total Environment 622-623: 783-789. DOI: 10.1016/j.scitotenv.2017.11.356

Walter G., Alekhin V.V. 1936. Fundamentals of Botanical Geography. Moscow; Leningrad: Biomedgiz. 715 p. [In Russian]

Winter S.L., Hickman K.R., Goad C.L., Fuhlendorf S.D., Gregory M.S. 2013. Seasonal Fires, Bison Grazing, and the Tallgrass Prairie Forb Arnoglossum plantagineum Raf. Natural Areas Journal 33(3): 327-338. DOI: 10.3375/043.033.0311

Winter S.L. Allred B.W., Hickman K.R., Fuhlendorf S.D. 2015. Tallgrass prairie vegetation response to spring fires and bison grazing. The Southwestern Naturalist 60(1): 30-35. DOI: 10.1894/FMO-19.1

Yaroshenko P.D. 1961. Geobotany. Moscow; Leningrad: Publishing house of the AS USSR. 474 p. [In Russian]

Yunusbayev U.B., Abdulina K.Kh. 2010. Influence of different timing of fires on the regrowth of aboveground phytomass in steppes of the Bashkir Transural region. Russian Journal of Ecology 41(1): 60-62. DOI: 10.1134/ S106741361001011X

Yunusbayev U.B., Abdulina K.Kh., Yanturin S.I. 2007. The role of fires in the formation of above-ground phytomass of steppe pastures in Transural part of the Republic of Bashkortostan. Agrarian Russia 5: 24-25. [In Russian] 


\title{
ВЛИЯНИЕ ПОЖАРА НА ДИНАМИКУ НАДЗЕМНОЙ ФИТОМАССЫ СТЕПНЫХ ФИТОЦЕНОЗОВ БУРТИНСКОЙ СТЕПИ (ОРЕНБУРГСКИЙ ГОСУДАРСТВЕННЫЙ ПРИРОДНЫЙ ЗАПОВЕДНИК, РОССИЯ)
}

\author{
Г. Х. Дусаева*, О. Г. Калмыкова, Н. В. Дусаева \\ Институт степи УрО РАН, Россия \\ *e-mail:16guluy@mail.ru
}

\begin{abstract}
В Оренбургской области степная зона подвержена сильнейшей антропогенной нагрузке, большая часть степей распахана, остальные земли используются под сенокосы и пастбища или не обрабатываются и представляют собой залежи. Частые пожары являются еще одной серьезной угрозой для биологического разнообразия степей региона. Данная проблема актуальна не только для территорий, используемых в сельском хозяйстве, но и для заповедников. Необходимость изучения последствий пожаров на экосистемы в государственном природном заповеднике «Оренбургский» назрела давно, как только стало ясно, что в связи со спецификой (значительная протяженность фронта и площадь выгорания, высокая скорость распространения при сильном ветре и т.д.) и с учащением степных пожаров, охрана заповедной территории не всегда решает проблему обеспечения сохранности степей. В то же время, именно на заповедных территориях с сохранившимися и подверженными наименьшему влиянию антропогенного фактора экосистемами представляется возможным и наиболее доступным проведение экологических исследований. Это дополняется исключением влияния других воздействий на этих территориях и возможностью использования данных, накопленных ранее в ходе многолетних наблюдений. Нами изучена динамика запасов надземной фитомассы после воздействия пожара на территории государственного природного заповедника «Оренбургский» участка «Буртинская степь». Территория исследования расположена в

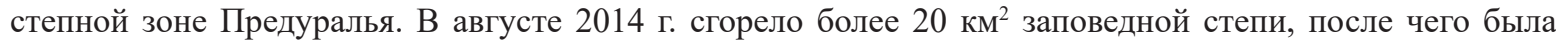
заложена мониторинговая сеть, состоящая из 6 участков, каждый участок включал в себя контрольную (негоревшую) и горевшую площадку. Исследования были проведены в период 2015-2016 гг. В каждом сообществе проводили геоботанические описания и укосы надземной фитомассы в весенний, летний, осенний период. Полученные образцы высушивали, разделяли по группам (злаки, разнотравье, полукустарнички) и взвешивали. В результате сравнения негоревших и пострадавших от огня площадок на всех участках выявились статистически значимые различия по U-критерию Манна-Уитни $(\alpha<0.05)$ в общих запасах надземной фитомассы, запасах мертвой фитомассы, ветоши злаков, подстилки. В горевших фитоценозах происходило смещение пиков накопления живой надземной фитомассы злаков и разнотравья по сравнению с контрольными площадками. В первые два года после пожара восстанавливаются только запасы живой надземной фитомассы и ее компонентов (злаков, разнотравья, полукустарничков), остальные фракции надземной фитомассы не достигают контрольных значений. Наши наблюдения, являлись частью проекта по созданию основы мониторинга экосистем на заповедном участке после пожара 2014 г., поддержанного ПРООН/ГЭФ/МПР РФ «Совершенствование системы и механизмы управления ООПТ в степном биоме России».
\end{abstract}

Ключевые слова: надземная фитомасса, Оренбургская область, особо охраняемая природная территория, пирогенный фактор 